\title{
Implementasi Konten E-Learning Mata Kuliah Fisika Studi Kasus: D3 Teknik Komputer, Universitas Telkom
}

\author{
Reza Budiawan ${ }^{1}$, Lisda Meisaroh ${ }^{2}$ \\ ${ }^{1}$ D3 Manajemen Informatika, Fakultas Ilmu Terapan, Universitas Telkom \\ ${ }^{2}$ D3 Teknik Komputer, Fakultas Ilmu Terapan, Universitas Telkom \\ 1,2 Jl. Telekomunikasi no 1, Dayeuh Kolot, Bandung, 40257 \\ email : ${ }^{1}$ rbudiawan@ tass.telkomuniversity.ac.id, ${ }^{2}$ lisda@tass.telkomuniversity.ac.id
}

\begin{abstract}
Abstrak - Mata kuliah Fisika yang diselenggarakan oleh program studi D3 Teknik Komputer, Fakultas Ilmu Terapan, Universitas Telkom merupakan mata kuliah dengan pemahaman dasar yang akan digunakan pada mata kuliah lanjutan di semester berikutnya. Salah satu cara untuk memperkuat pemahaman dari mata kuliah ini yaitu dengan cara melakukan visualisasi materi dan penambahan interaktifitas bagi kuliah teori yang biasanya terlalu tekstual. Metode pembelajaran ini dinamakan metode blended learning. Metode ini menggabungkan antara metode konvensional dan konten e-learning sebagai suplemen pemahaman dalam proses belajar mengajar. Penelitian ini menghasilkan konten e-learning untuk digunakan pada penerapan metode blended learning di mata kuliah Fisika, program studi D3 Teknik Komputer, Fakultas Ilmu Terapan. Selain menghasilkan konten $e$ learning, penelitian ini juga mengukur konten e-learning tersebut dengan menggunakan beberapa aspek pengukuran yang dilihat dari perspektif mahasiswa. Pembangunan konten e-learning pada penelitian ini menggunakan metode Prototype dengan hasil penelitian terbagi dari dua kelompok, yaitu konten pembelajaran serta hasil pengukuran dari aspek user experience dari konten pembelajaran.
\end{abstract}

Kata kunci - Fisika, konten e-learning, pengukuran konten e-learning, animasi interaktif.

Abstract_Physics course that held at Diploma of Computer Engineering in School of Applied Science, Telkom University is a prerequisite courses which has basic concept and theory. This condition makes Physics get more attention as it held in every semester. Physics is an important course for Diploma of Computer Engineering, because the concept in this course will be implemented in Embedded System course which is an advanced course. Blended learning system is a method that can be implemented to make students understands about the concept and theory in Physics courses. Visualizing of bored-textual course to become an interesting picture, video, or interactive animation is the basic needs of blended learning. In order to support blended-learning method for Physics course, this study has built a bunch of learning content for Physics course. Besides, several aspects of the contents are review from student's perspective. The result of this study can be used as a supplement learning-teaching in blended learning method.

Keywords - Physics course, e-learning content, interactive animation.

\section{PENDAHULUAN}

Fisika merupakan mata kuliah dasar yang harus dipahami mahasiswa D3 Teknik Komputer, Fakultas Ilmu Terapan, Universitas Telkom, untuk menguasai mata kuliah lanjutan di Program Studi Teknik Komputer. Setelah mengikuti mata kuliah ini, mahasiswa dapat menerapkan konsep-konsep fisika dalam mata kuliah Elektronika Dasar dan mata kuliah pada peminatan Embedded System. Dikarenakan hal tersebut, Mata Kuliah Fisika harus dipahami dengan baik, dan salah satu cara untuk membantu pemahaman mahasiswa adalah melakukan pembelajaran dengan keterangan visual. Selain itu dibutuhkan alat bantu yang dapat membantu mahasiswa mengingat cara penyelesaian soal Fisika terkait penggunaan rumus beserta penjabaran dari rumus tersebut.

Mata kuliah Fisika memiliki karakteristik sebagai mata kuliah yang menganjarkan prinsip berdasarkan fakta. Mata kuliah ini mempelajari hukum alam dan berbagai komponen kelistrikan dengan sifatnya masing-masing. Tetapi dalam pengajarannya, mata kuliah Fisika tidak mengungkapkan hal tersebut dikarenakan sifatnya yang lebih menekankan konsep keilmuannya. Hal ini membuat pemahaman mahasiswa tidak menjadi maksimal dalam proses belajar mengajar.

Dilihat dari histori pembelajaran yang pernah dilakukan, hanya $6,58 \%$ mahasiswa yang berhak mendapatkan nilai memuaskan (A), 34,21\% mendapat nilai rata-rata (indeks $\mathrm{B}$ dan $\mathrm{C}$ ), sedangkan sisanya $(59,21 \%)$ tidak lulus mata kuliah tersebut. Hal ini berdampak pada pemahaman yang dimiliki mahasiswa untuk mengambil mata kuliah peminatan Embedded System.

Pada proses pembelajaran di kelas, pemahaman konsep dan pengerjaan soal dilakukan secara 
bergantian. Bobot pendalaman materi dan pengerjaan soal yang berjumlah 3 (tiga) SKS telah diatur dalam kurikulum dengan rincian sebagai berikut: (1) Tutorial: 1 x 50 menit, (2) Praktek: 1 x 50 menit, dan (3) Praktikum: 2x 50 menit. Pada saat tutorial mahasiswa diberikan konsep tentang materi yang dipelajari. Pada saat praktikum, mahasiswa mencoba dengan panduan yang disediakan. Sedangkan saat praktek, mahasiswa melakukan tugas tanpa panduan. Pada saat praktikum, panduan tidak efektif dilakukan hanya berdasarkan langkah yang ada di buku atau modul praktikum. Dibutuhkan contoh berupa langkah khusus yang divisualisasikan sehingga bisa diimitasi untuk menyelesaikan tugas yang dimaksud. Penelitian ini membahas tentang penggunaan e-learning dari segi konten pembelajaran sebagai media untuk membantu pemahaman mahasiswa dalam memahami materi perkuliahan.

Electronic Learning atau biasa disingkat $e$ learning merupakan tipe pembelajaran yang didukung oleh teknologi. Biasanya, pada tipe pembelajaran $e$ learning, tidak terdapat interaksi tatap muka antara instruktur dan siswa/mahasiswa. Hal ini memiliki kekurangan tersendiri dikarenakan setiap siswa membutuhkan motivasi dari pengajar. Motivasi ini hanya dapat diberikan secara efektif ketika dilakukan secara tatap muka. Untuk mengatasi hal tersebut, terdapat sebuah metode e-learning yang memungkinkan untuk menggabungkan antara metode konvensional (pembelajaran di kelas) dengan penggunaan teknologi. Metode ini disebut metode blended learning [1].

Pembelajaran online dalam e-learning cukup efektif untuk dilakukan. Hanya saja perencanaan sistem yang komplek dibutuhkan untuk melangsungkan proses pembelajaran. Selain itu, dibutuhkan juga perencanaan proses pembelajaran yang fleksibel yang memungkinkan siswa/mahasiswa me-manage hal-hal apa yang sudah dilakukan [2].

Banyak hal cara yang dapat dilakukan untuk menerapkan e-learning dalam perkuliahan. Contohnya, pada Prosiding Pertemuan Ilmiah XXVIII HFI Jateng \& DIY, Assa'idah dan Menik Ariani [3] menerapkan e-learning pada mata kuliah Fisika Komputasi melalui tutorial online, maupun script komputasi. Script yang dibuat merupakan script pemrograman terkait permasalahan yang harus diselesaikan. Tutorial disajikan melalui video tutorial berisi penjelasan konsep fisis. Sedangkan, untuk scripting, digunakan untuk membahas permasalahan teori dan pembuktian penerapan teori pada soal yang diberikan. Hasil evaluasi akhir pada penelitian ini berhasil meningkatkan pencapaian nilai A menjadi sebesar $20.6 \%$, dan menurunkan pencapaian grade $\mathrm{C}$ sebesar 5\% dari tahun sebelumnya.

Contoh penerapan lain dari implementasi $e$ learning dilakukan oleh Siti Nur Alfath [4] yaitu membuat sebuah sarana perkuliahan blended learning berbasis web enhanced course. Penelitian ini meneliti pengaruh media belajar dengan minat belajar juga peningkatan hasil belajar mahasiswa di Universitas Negri Semarang. Hasil dari penelitian itu yaitu media pembelajaran yang dibuat mampu menumbuhkan minat belajar sebesar $76 \%$ kategori tinggi, dan meningkatkan hasil belajar 0,32 kategori sedang.

Clemens Nagel dan Brigitte Wolny [5] membangun sistem blended learning untuk sembilan puluh eksperimen pada empat modul laboratorium. Eksperimen dibangun sebagai bentuk interactive learning menggunakan Java-Applet, demo kegiatan lab dalam bentuk video, dan beberapa materi suplemen yang diberikan dalam eksternal link ataupun embedd material. Pada pembangunan sistem tersebut, terdapat tiga tahapan utama yang dilakukan, yaitu: analisis konten materi pembelajaran, investigasi dari perspektif mahasiswa, dan melakukan desain terhadap learning environment berdasarkan dua tahapan sebelumnya. Setiap tahapan ini terhubung satu sama lain untuk menghasilkan sebuah sistem blended learning yang dapat membantu proses belajar.

Hal yang hampir serupa dilakukan oleh Sergej Faletic dan timnya [6]. Mereka melakukan pembangunan sistem e-learning berdasarkan 3 permasalahan utama, yaitu: kurangnya materi interaktif, soal dan permasalahan yang diangkat pada materi Fisika terlalu teoritis, dan kurangnya feedback. Berdasarkan hal tersebut, material sistem e-learning dibangun serealitis mungkin dengan representasi objek dunia nyata. Sistem ini dibangun oleh dua kelompok tim, yaitu kelompok yang memahami Fisika dan kelompok yang fokus pada pengembangan Information Communication Technology (ICT). Sistem yang mereka kembangkan merupakan web portal berbasiskan Ajax. Selain itu digunakan pula tools Flash untuk menyediakan interactivity, XML dan CSV sebagai data storage, Fwiki untuk penulisan konten, dan JavaScript untuk menyatukan semua hal tersebut.

Contoh lain penerapan blended learning pada rumpun materi Fisika, terdapat pada penelitian yang dilakukan oleh Ida Sriyanti [6]. Penelitian ini berbeda dengan penelitian sebelumnya yang telah disebutkan. Penekanan penelitian terdapat pada penelitian tindakan kelas (PTK), bukan fokus pada pengembangan materi ajar sebagai suplemen mahasiswa. Penggunaan metode blended learning digunakan dikarenakan alasan yang sama dengan penelitian lain, yaitu kebutuhan akan representasi visual seperti grafik ataupun gambar yang lebih mudah diamati dan dipelajari. Pada penelitian ini dijelaskan langkahlangkah detail untuk melakukan PTK menggunakan blended learning, termasuk tahapan metode yang digunakan dengan parameter hasil penelitian berupa ketuntasan belajar.

\section{METODOLOGI PENELITIAN}

Penelitian ini dilaksanakan di lingkungan program studi D3 Teknik Komputer, Fakultas Ilmu Terapan. Penelitian ini akan menghasilkan konten pembelajaran dari mata kuliah Fisika untuk dapat 
diterapkan sebagai bagian dari pembelajaran bertipe e-learning, khususnya blended learning. Konten pembelajaran yang dihasilkan akan diukur menggunakan kuesioner yang disebar ke mahasiswa D3 Teknik Komputer, Fakultas Ilmu Terapan, Universitas Telkom.

Konten pembelajaran dibangun menggunakan metode Prototype. Metode ini membagi tahapan pembangunan konten pembelajaran ke dalam 3 bagian: "Listen to Customer", "Build/Revise MockUp", dan "Customer Test Drives Mock-Up". Model Prototype dilakukan secara berulang dikarenakan tujuan awal bersifat umum tanpa mendetailkan masukan, proses dan keluaran sistem. Model tersebut digambarkan pada Gambar 1[8].

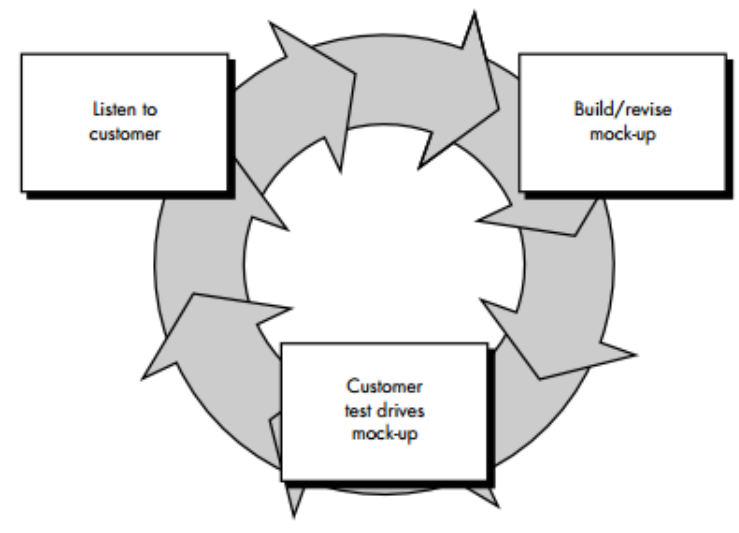

Gambar 1. Model Prototype

Pada tahapan Listen to Customer, hal yang dilakukan yaitu merumuskan tentang bentuk pembelajaran e-learning seperti apa yang akan dibangun, termasuk pengubahan bentuk tekstual ke dalam bentuk visual. Setelah membicarakan bentuk $e$ learning, ditentukan tema yang akan digunakan saat membentuk konten pembelajaran nantinya. Pada tahap kedua, mock-up dibangun dan setelahnya, masuk ke tahapan ketiga, yaitu merevisi mock-up sesuai keinginan dari dosen pengajar mata kuliah Fisika.

Proses dari model Prototype dilakukan berulangulang secara periodik selama pembangunan sistem. Pembangunan dan review pada penelitian ini ditetapkan sebanyak tiga kali. Hasil akhir berupa konten pembelajaran, dievaluasi oleh beberapa pihak, yaitu: dosen pengajar mata kuliah Fisika, mahasiswa yang akan diajar (pada semester berikutnya), dan tim dosen yang merupakan reviewer dari unit Bagian Pengembangan Pengajaran.

\section{HASIL \& PEMBAHASAN PENELITIAN}

Sesuai dengan metode penelitian yang digunakan, terdapat tiga tahapan yang dilakukan pada tahapan penelitian. Pada tahapan pertama, dilakukan analisis terhadap konten pembelajaran dari tim dosen mata kuliah Fisika. Tahapan pertama dijelaskan pada $s u b$ bagian A dari Hasil \& Pembahasan Penelitian.
Hasil dari penelitian ini, terbagi ke dalam dua kelompok, yaitu konten pembelajaran dan hasil penerimaan dari dokumen pembelajaran tersebut terhadap mahasiswa yang akan mendapat mata kuliah Fisika di semester berikutnya. Umpan balik yang diberikan merupakan hal-hal terkait konten pengajaran dan penerapannya pada pengajaran. Hal yang telah disebutkan sebelumnya, dijelaskan pada $s u b$-bagian B dan C dari Hasil \& Pembahasan Penelitian.

\section{A. Pembelajaran Fisika D3 Teknik Komputer, Fakultas Ilmu Terapan, Universitas Telkom}

D3 Teknik Komputer merupakan salah satu program studi di Fakultas Ilmu Terapan, Universitas Telkom. Pembelajaran dan evaluasi di D3 Teknik Komputer dilakukan dengan metode assessment. Pembelajaran dengan metode ini dilakukan dengan cara memberikan membagi materi ke dalam beberapa kelompok kajian tertentu. Kelompok kajian ini memiliki empat kategori keahlian yang harus dipahami. Sehingga, setiap kategori keahlian memiliki penilaian minimum bernilai 25 dalam bentuk kuantitatif.

Evaluasi diberikan kepada mahasiswa jika materi telah selesai diberikan dan disampaikan. Proses evaluasi ini dinamakan assessment. Penilaian dari proses assessment dibagi ke dalam lima kategori kompetensi: (1) Tidak Lulus, (2) Dasar, (3) Menengah, (4) Cukup Mahir, dan (5) Mahir. Setiap kategori memiliki arti kualitatif bagi pencapaian yang telah dimiliki mahasiswa untuk setiap keahlian yang ditentukan. Kategori tersebut dirumuskan oleh koordinator mata kuliah dengan persetujuan dari tim dosen saat rapat dosen di perkuliahan pertama.

Untuk menjembatani antara proses kualitatif dan kuantitatif, pemetaan dilakukan dengan pemberian nilai batas bawah dan batas atas untuk setiap kategori kompetensi.

Pemetaannya dituliskan sebagai berikut.

1. Tidak Lulus: 0-5

2. Dasar: 6-10

3. Menengah: 11-15

4. Cukup Mahir: 16-20

5. Mahir: 21-25

Pemetaan antara kategori kualitatif dengan nilai kuantitatif yang digunakan pada mata kuliah Fisika:

Tabel 1. Pemetaan Nilai Kualitatif-Kuantitatif

\begin{tabular}{clc}
\hline Kompetensi & \multicolumn{1}{c}{ Kriteria Penilaian } & Penilaian \\
\hline Tidak Lulus & $\begin{array}{l}\text { Tidak memenuhi kriteria } \\
\text { penilaian kompetensi dasar }\end{array}$ & $0-5$ \\
& $\begin{array}{l}\text { Mampu Menyelesaikan >= } \\
\text { 50\% Indikator Kompetensi } \\
\text { Dang diujikan }\end{array}$ & $6-10$ \\
& $\begin{array}{l}\text { Mampu Menyelesaikan >= } \\
\text { 60\% Indikator Kompetensi } \\
\text { yang diujikan }\end{array}$ & \\
& &
\end{tabular}


Implementasi Konten E-Learning Mata Kuliah Fisika Studi Kasus: D3 Teknik Komputer, Universitas Telkom

\begin{tabular}{clc}
\hline Kompetensi & \multicolumn{1}{c}{ Kriteria Penilaian } & Penilaian \\
\hline \multirow{3}{*}{ Cukup Mahir } & $\begin{array}{l}\text { Mampu Menyelesaikan >= } \\
\text { 70\% Indikator Kompetensi } \\
\text { yang diujikan }\end{array}$ & 16-20 \\
& $\begin{array}{l}\text { Mampu Menyelesaikan >= } \\
\text { Mahir }\end{array}$ & $\begin{array}{l}\text { 80\% Indikator Kompetensi } \\
\text { yang diujikan }\end{array}$ \\
\hline
\end{tabular}

Terdapat beberapa kelompok kajian pencapaian pembelajaran. Kelompok kajian tersebut dituliskan pada Tabel 2.

Tabel 2. Kategori Pembahasan

\begin{tabular}{ll}
\hline Kelompok Kajian & \multicolumn{1}{c}{ Materi Pembahasan } \\
\hline Kajian 1 & Pengukuran, Hukum Newton \\
& Gerak \\
& Usaha, Energi, Daya \\
& Momentum, Impuls \\
& Osilasi \\
& Gelombang \\
& Bunyi \\
Kajian 2 & Listrik Statis \\
& Listrik Searah 1 \\
& Listrik Searah 2 \\
& Medan Magnet \\
& Gelombang Elektromagnetik \\
\hline
\end{tabular}

\section{B. Konten Pembelajaran}

Konten pembelajaran e-learning yang dibangun merupakan animasi interaktif dengan materi pembahasan ditentukan oleh dosen pengajar Fisika. Animasi materi pembahasan yang dibangun, ditentukan dengan mempertimbangkan pemahaman yang memerlukan pembahasan dalam bentuk visual. Berdasarkan hal tersebut, modul konten pembelajaran digambarkan pada Gambar 2.

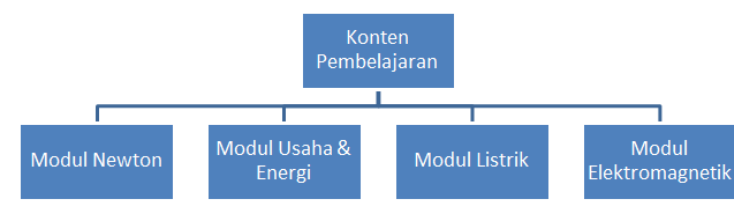

Gambar 2. Modul Konten Pembelajaran

Konten pembelajaran merupakan animasi interaktif yang terbagi ke dalam empat modul, yaitu: Modul Newton, Modul Usaha \& Energi, Modul Listrik, dan Modul Elektromagnetik. Setiap modul memiliki bagian penjelasan dan latihan. Selain itu, ada video non-interaktif sebagai bentuk pengenalan mata kuliah Fisika pada proses pembelajaran mahasiswa D3 Teknik Komputer.

Modul Newton merupakan modul untuk mempelajari hukum Newton. Terdapat beberapa penjelasan untuk materi hukum Newton, serta soalsoal yang ditampilkan. Pada modul ini, embodied agent ditambahkan agar proses belajar menjadi lebih terasa "interaktif'. Menu utama dari modul Newton ditampilkan pada Gambar 3. Sedangkan hirarkis pembelajaran terlihat pada Gambar 4.

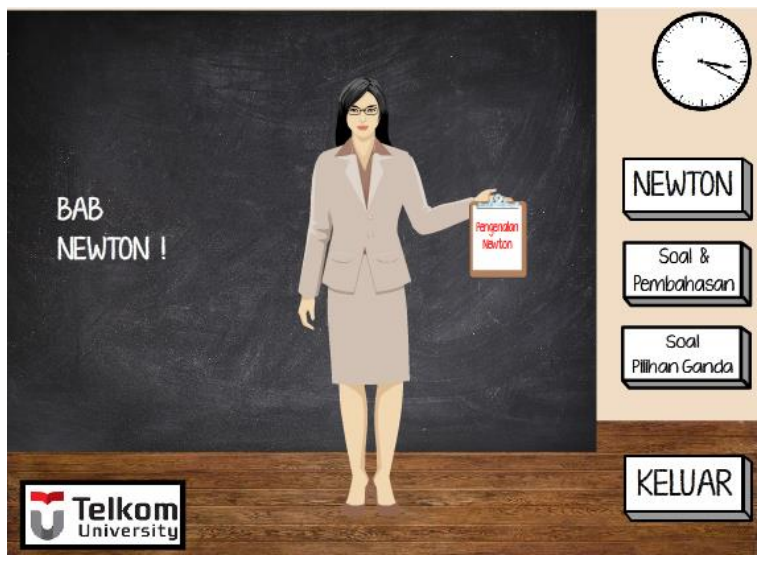

Gambar 3. Menu Utama Konten Pembelajaran

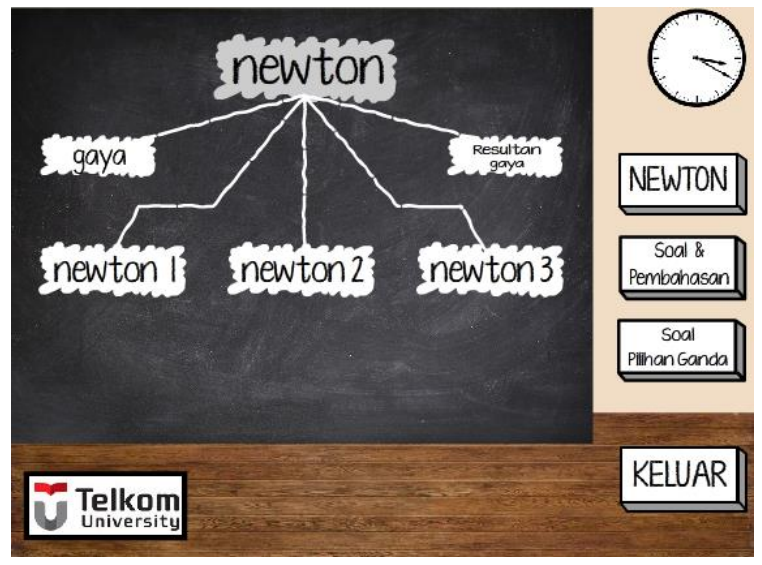

Gambar 4. Hirarkis Pembelajaran

Hirarkis pembelajaran ini dimaksudkan agar mahasiswa dapat mempelajari materi secara berurutan. Mahasiswa dapat memilih salah satu materi yang ingin diketahui penjelasannya. Penjelasan dari setiap materi diberikan secara ringkas dengan tambahan rumus esensi yang menjadi inti dari materi. Hal ini dilakukan dikarenakan tipe pembelajaran yang bersifat blended learning. Penambahan konten merupakan suplemen bagi mahasiswa untuk mempelajari materi. Selain itu, penjelasan ini juga diberikan dalam bentuk animasi. Contoh dari gerakan animasi diperlihatkan pada Gambar 5 dan Gambar 6. 


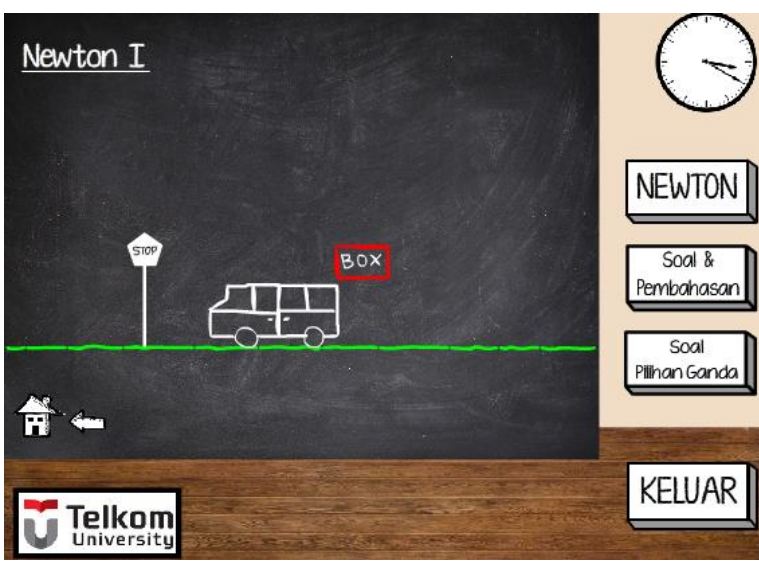

Gambar 5. Animasi Hukum Newton 1

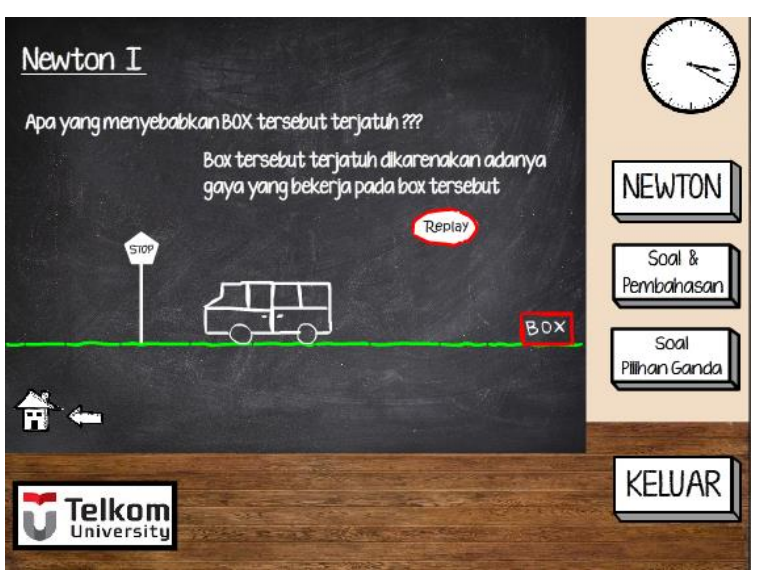

Gambar 6. Animasi dan Penjelasannya

Modul usaha dan energi serta modul yang lain memiliki sifat yang sama dengan modul Newton. Pada modul ini juga disertai soal-soal yang dilengkapi dengan ilustrasi sesuai deskripsi soal. Contoh dari soal beserta ilustrasi pada modul Usaha dan Energi ditampilkan pada Gambar 7 dan Gambar 8.

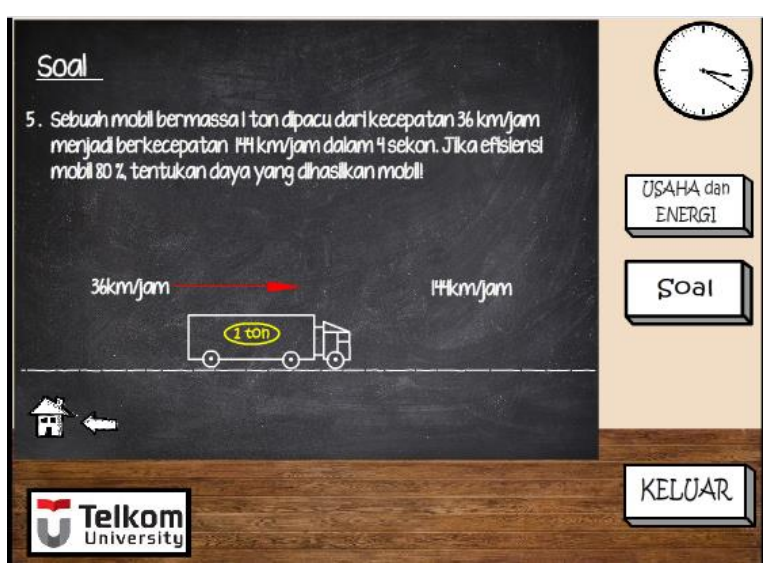

Gambar 7. Kondisi Awal Ilustrasi Soal

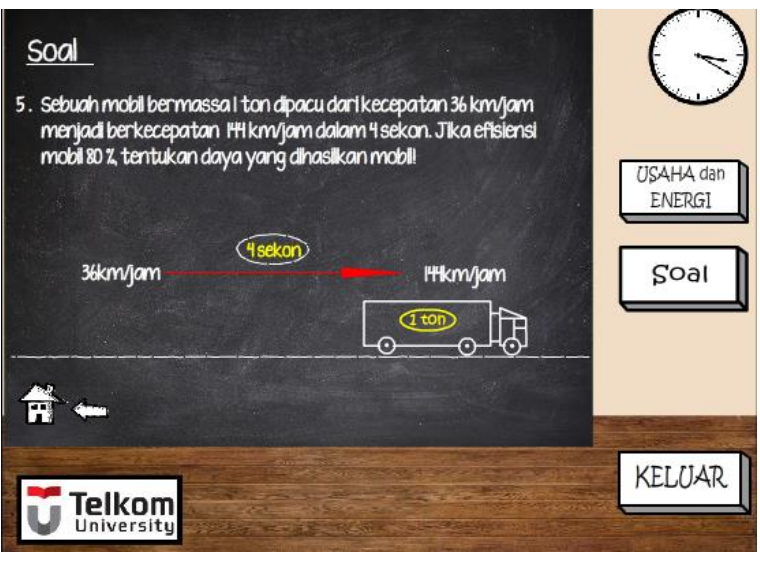

Gambar 8. Kondisi Akhir Ilustrasi Soal

Selain ilustrasi soal, terdapat pula soal yang harus dijawab dalam bentuk pilihan ganda.Contoh soal pilihan ganda yang terdapat pada modul Listrik, dapat dilihat pada Gambar 9.

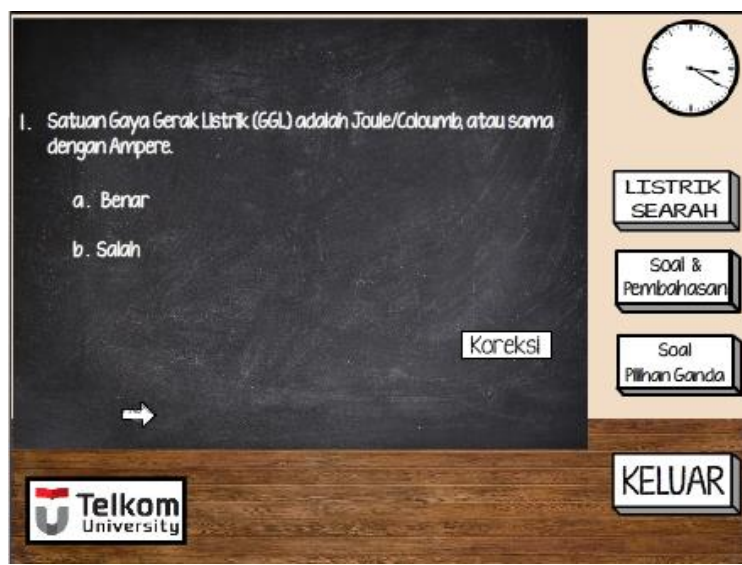

Gambar 9. Contoh Soal Pilihan Ganda

Tidak semua modul memiliki soal bertipe pilihan ganda. Hal ini dikarenakan ada beberapa materi yang membutuhkan pemahaman lebih, sehingga soal dalam bentuk pilihan ganda menjadi bentuk latihan yang kurang tepat untuk diberikan.

\section{Penerapan Konten Pembelajaran}

Konten pembelajaran yang telah dihasilkan diterapkan pada kelas D3 Teknik Komputer. Konten multimedia tersebut dipresentasikan kepada mahasiswa untuk menilai tentang konten pembelajaran. Aspek yang ditanyakan mencakup tampilan animasi, kejelasan menu \& materi, penggunaan aplikasi untuk pemahaman materi, penambahan latihan pada aplikasi, dan kemudahan pemahaman kalimat.

Untuk tampilan animasi, 54\% responden menjawab dengan "Baik" dan "Sangat Baik". Hal ini merupakan hal yang cukup bagus dikarenakan hanya $3 \%$ responden yang menjawab tampilan animasi belum cukup baik untuk mengilustrasikan materi yang divisualisasikan. Hasil kuesioner tersebut diperlihatkan pada Gambar 10. 


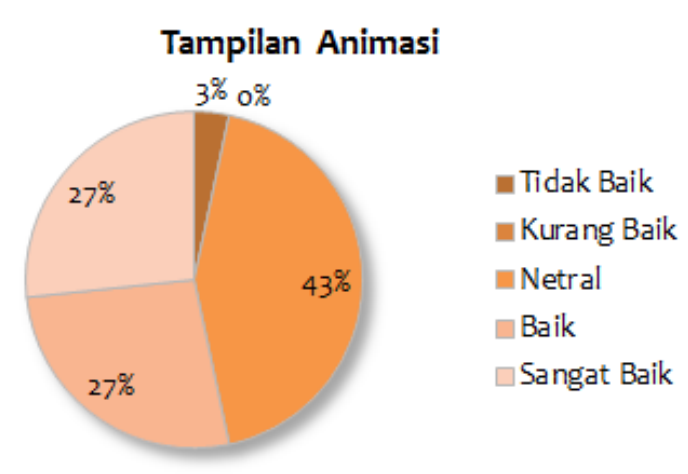

Gambar 10. Hasil Kuesioner Tampilan Animasi

Berdasarkan kejelasan menu materi, $64 \%$ responden menjawab dengan hasil "Sangat Baik" dan "Baik". Tidak ada yang menjawab "Tidak Baik". Hanya 3\% responden yang menjawab bahwa menu materi kurang jelas untuk menggambarkan materi yang diberikan. Hasil kuesiner terkait kejelasan menu materi diperlihatkan pada Gambar 11.

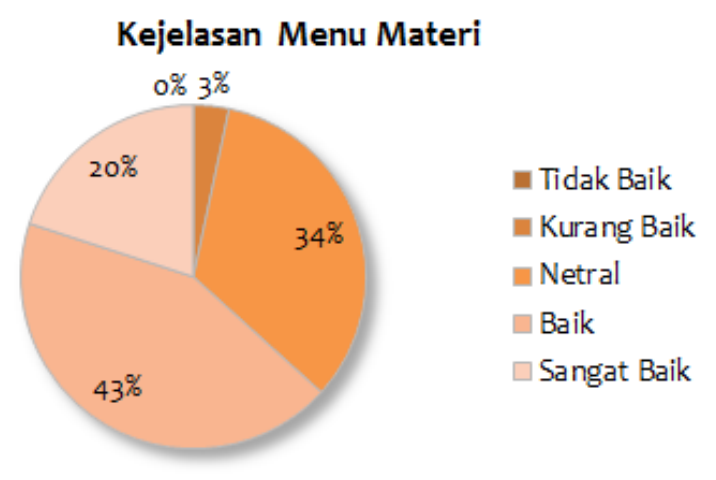

Gambar 11. Hasil Kuesioner Kejelasan Menu Materi

Dilihat dari aspek penggunaan aplikasi sebagai media bantu belajar, $77 \%$ responden menjawab dengan respon yang positif. Mereka yakin akan bantuan aplikasi sebagai media pembantu untuk memahami materi yang diberikan oleh dosen pengajar di kelas. Hasil dari kuesioner ini diperlihatkan pada Gambar 12.

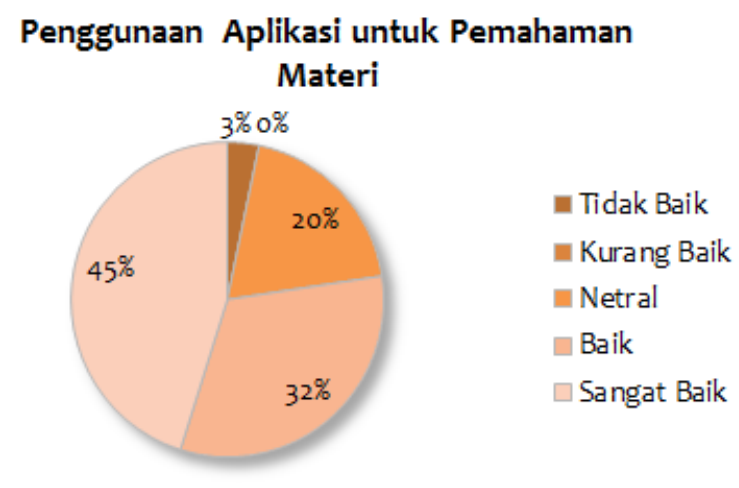

Gambar 12. Hasil Kuesioner Penggunaan Aplikasi Sebagai Media Bantu Pemahaman Materi
Sebagai tambahan yang esensi pada konten pembelajaran, pemberian latihan merupakan aspek yang cukup penting untuk dinilai. Berdasarkan kuesioner yang disebar, 59\% responden menjawab bahwa latihan yang diberikan pada konten aplikasi telah cukup baik. Detail penilaian yang diberikan dapat dilihat pada Gambar 13.

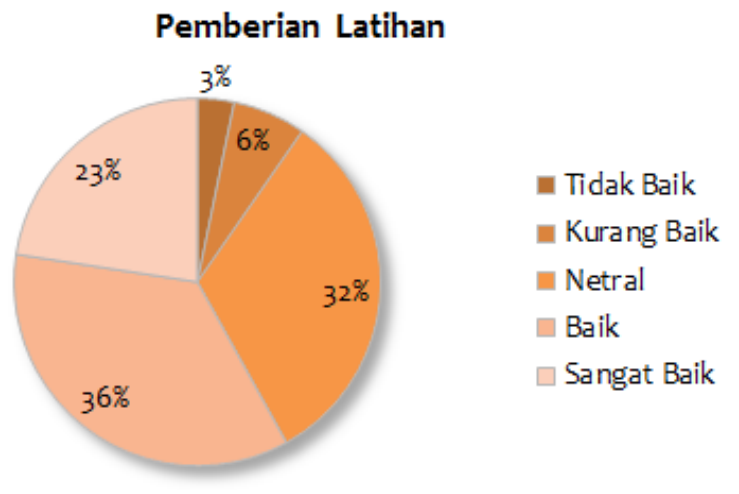

Gambar 13. Hasil Kuesioner Tentang Pemberian Latihan

Hal terakhir yang diamati pada penelitian ini yaitu tentang kemudahan dalam memahami kalimat. Pemahaman kalimat yang diberikan tidak hanya mencakup konten pembelajaran interaktif, tetapi juga konten pembelajaran non-interaktif (dalam bentuk video pembelajaran). Pada kriteria ini, 70\% menjawab bahwa kalimat yang digunakan bisa dipahami dengan baik. Detail hasil kuesioner terkait aspek ini ditunjukkan oleh Gambar 14.

\section{Kemudahan Pemahaman Kalimat}

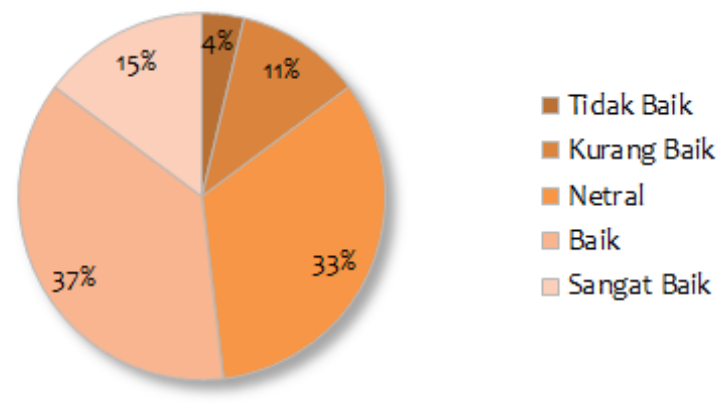

Gambar 14. Hasil Kuesioner Tentang Pemahaman Kalimat yang Diberikan

Berdasarkan hasil kuesioner di atas, lebih dari $50 \%$ responden menilai dengan kriteria "Baik" dan "Sangat Baik" hampir di seluruh aspek penilaian. Hal ini memperlihatkan antusiasme mahasiswa untuk menggunakan aplikasi interaktif sebagai media bantu belajar dari tipe pembelajaran blended learning.

\section{PENUTUP}

\section{A. Kesimpulan}

Penelitian ini menghasilkan konten pembelajaran dari beberapa materi yang telah ditetapkan sebagai standar kompetensi pemahamaman mahasiswa D3 
Teknik Komputer, Fakultas Ilmu Terapan, Universitas Telkom. Selain itu, berdasarkan hasil kuesioner, mahasiswa merasa antusias untuk menjadikan animasi interaktif dan non-interaktif sebagai alat bantu belajar dalam memahami materi yang diberikan. Hal ini memperlihatkan bahwa blended learning dapat diterapkan pada mahasiswa program studi D3 Teknik Komputer.

\section{B. Saran}

Pengembangan lebih baik dapat dilakukan pada penambahan konten materi ajar untuk melengkapi media interaktif sebagai alat bantu ajar. Selain itu, pada soal, sebaiknya tidak hanya disertai ilustrasi, tetapi juga scripting program yang dapat mengilustrasikan cara kerja dari teori yang diberikan.

\section{UCAPAN TERIMA KASIH}

Terima kasih kepada mahasiswa program studi D3 Teknik Komputer, tim dosen pengajar mata kuliah Fisika, unit Bagian Pengembangan Pengajaran Universitas Telkom yang telah melakukan review terhadap penelitian ini.

\section{DAFTAR PUSTAKA}

[1] Martin-Blas, Teresa. "E-Learning Platforms in Physics Education". 2009. Taken from: cdn.intechopen.com/pdfs-wm/9416.pdf

[2] Jonsson, Bo-Anders." A case study of successful elearning: A web-based distance course in medical physics held for school teachers of the upper secondary level". Journal of Medical Engineering \& Physics 27. 2005. pp 571-581. Elsevier.

[3] Assa'idah dan Ariani, Menik. "Metode e-Learning Untuk Peningkatan Hasil Belajar Peserta Kuliah Fisika Komputasi". 2014. Taken from: http://hfidiyjateng.or.id/

[4] Affath, Siti Nur. "Pengembangan Media Blended Learning Berbasis Web Enhanced Course pada Mata Kuliah Fisika Dasar 2 Jurusan Fisika Unnes". Semarang.2013. Taken from: http://lib.unnes.ac.id/17900/1/4201408087.pdf

[5] Nagel, C. \& Wolny, B. "eLearning in the Introductory Physics Lab". In J. Luca \& E. Weippl (Eds.), Proceedings of EdMedia: World Conference on Educational Media and Technology 2008. pp. 60096014.

[6] Faletič, Sergej, Gorazd Planinšič, and Boris Horvat. "Interactive e-learning content for physics". GIREPICPE-MPTL, 2010.

[7] Sriyanti, Ida. "Penerapan Model Blended e-learning Pada Matakuliah Pendahuluan Fisika Zat Padat". In: Seminar Nasional Fisika: Palembang.2012.

[8] Pressman, Roger S. "Software Engineering: A Practitioner's Approach". 5th edition: McGraw-Hill. 
ISSN : 2085-3688; e-ISSN : 2460-0997

Implementasi Konten E-Learning Mata Kuliah Fisika Studi Kasus: D3 Teknik Komputer, Universitas Telkom 